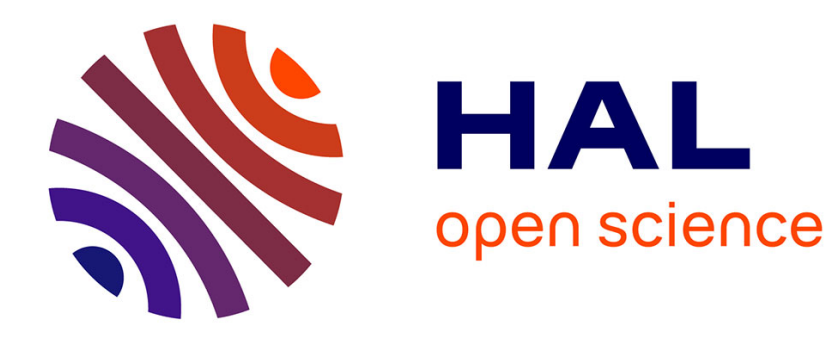

\title{
Multiple Large Shareholders and Earnings Informativeness
}

Sabri Boubaker, Hind Sami

\section{To cite this version:}

Sabri Boubaker, Hind Sami. Multiple Large Shareholders and Earnings Informativeness. Review of Accounting and Finance, 2011, 10 (3), pp.246 - 266. 10.1108/14757701111155789 . halshs-00623867

\section{HAL Id: halshs-00623867 https://shs.hal.science/halshs-00623867}

Submitted on 20 Sep 2011

HAL is a multi-disciplinary open access archive for the deposit and dissemination of scientific research documents, whether they are published or not. The documents may come from teaching and research institutions in France or abroad, or from public or private research centers.
L'archive ouverte pluridisciplinaire HAL, est destinée au dépôt et à la diffusion de documents scientifiques de niveau recherche, publiés ou non, émanant des établissements d'enseignement et de recherche français ou étrangers, des laboratoires publics ou privés. 


\title{
Multiple Large Shareholders and Earnings Informativeness
}

\author{
Sabri Boubaker ${ }^{\dagger}$ \\ Champagne Business School, Groupe ESC Troyes, France \\ Institut de Recherche en Gestion, Université Paris Est Créteil, France \\ and \\ Hind $\mathrm{Sami}^{\Psi}$ \\ COACTIS EA 4161 \\ Université Lyon 2, Lyon, France
}

\begin{abstract}
Purpose - The purpose of this paper is to add to our understanding of the monitoring role of multiple large shareholders by examining their impact on the informativeness of firms' earnings. Design/methodology/approach - We use regression models that relate earnings to stock returns for a sample of 402 French publicly traded firms covered during 2003-2007. Findings - We show that earnings informativeness is significantly positively related to the owner's ultimate cash flow rights. Consistent with the alignment effect, stock ownership aligns management and shareholders interests which reduces managers' incentives to manipulate accounting information. We also find that earnings informativeness is significantly negatively related to the excess control of the ultimate controlling shareholder. This result supports the entrenchment effect and suggests that controlling shareholders have greater incentives to obscure accounting figures when expropriation is likely. Finally, control contestability of the largest controlling shareholder mitigates information asymmetry problems thereby enhancing earnings informativeness. Limitations/implications - Our findings stress the importance of MLS in enhancing internal monitoring and mitigating agency costs. Because France is characterized by a weak legal system, highly concentrated ownership structures and excess control, our results provide valuable insights to mitigate extreme agency problems. Originality/value - The paper adds to the literature on corporate governance and the quality of accounting information by investigating strategic interactions between various blockholders and their impact on earnings informativeness. The study complements prior studies on the monitoring role of MLS by demonstrating that both their presence and control size translate into significantly greater earnings informativeness.
\end{abstract}

Key words: Multiple large shareholders; earnings informativeness; excess control

Article type: Research paper

\footnotetext{
$\dagger$ Champagne School of Management (Groupe ESC Troyes). Address: 217, Av. Pierre Brossolette, BP 710, 10002 Troyes Cedex, France. Tel. : +33 3257122 31; Fax.: +33 3254922 17; Email : sabri.boubaker@groupe-esctroyes.com

భ COACTIS EA 4161 - Université Lyon 2, ISH, 14-16, av. Berthelot, 69363 Lyon cedex 07. Email : hind.sami@ univlyon2.fr
} 


\section{Introduction}

Information is the lifeblood of financial markets. It is well recognized that the quality of corporate disclosure influences to a great extent the quality of investment decisions. Potential benefits of more disclosure include lower cost of capital (Diamond and Verrecchia, 1991), agency cost reduction (Leftwich et al., 1981) and improved share price (Gelb and Zarowin 2002; Lang and Lundholm 2000). To the extent that management has discretion over the quality of reported accounting information, a large literature on corporate governance has focused on the relation between managerial ownership and the quality of accounting information (Warfield et al., 1995). Departing from Berle and Means' (1932) seminal work on widely diffused corporate ownership, recent studies have focused on the conflicts of interest between controlling shareholders and minority shareholders (Villalonga and Amit, 2006; Ali et al., 2007). Specifically, when minority shareholders face possible expropriation by large controlling shareholders, the contest to the control is a key issue (See, e.g., Shleifer and Vishny, 1997; La Porta et al., 1999; Faccio and Lang, 2002; Maury and Pajuste, 2005).

The present paper contributes to prior research by further examining the impact of the distribution of ownership and the contest to the control on earnings informativeness in a concentrated ownership setting. More specifically, this study seeks to add to the understanding of the monitoring role of multiple large shareholders (MLS) by examining their impact on the informativeness of accounting earnings. Our study is carried out on a sample of 402 French publicly traded firms covered during the 2003-2007 period. France is characterized by a weak legal system and poor investors' protections laws which may in turn give rise to minority expropriation (La Porta et al. 1999). Indeed, French listed firms have highly concentrated ownership structures and control is enhanced via devices such as double voting shares and pyramiding. The control of French firms is often ensured through a relatively small proportion of cash flow rights compared to that of control rights (Faccio and Lang, 2002; Boubaker and Labegorre, 2008). These characteristics increase the potential for extreme agency problems between the large controlling shareholders and minority shareholders. In this paper, we investigate strategic interactions between various blockholders in order to examine the effects of multiple large shareholders on firms' quality of earnings information.

First, focusing on agency problems between controlling and minority shareholders we explore whether having more than one large shareholder in the firm plays as a disciplining device which in turn may translate into greater informativeness of accounting earnings. Because we believe that control of ultimate owners is more relevant in assessing the outcome of agency conflicts we focus on the distribution of ultimate control rights. Warfield et al. (1995) focus on the ownership incentive effects and find that earnings quality is generally increasing in the level of managerial 
ownership. Because stock ownership aligns management's interests with those of shareholders, it hence reduces or eliminates managers' incentives to manipulate accounting information. Fan and Wong (2002), in turn, examine a sample of East Asian firms. They suggest that concentrated ownership is associated with low quality earnings since controlling shareholders may report selfinterestedly and may have incentives to disclose as little proprietary information as possible. We contribute to the unresolved debate by empirically examining the relation between the presence of large controlling shareholders and firm's earnings informativeness.

Second, we study the interaction between main large shareholders in concentrated ownership context by examining the effects of voting size and voting distribution among them on the quality of firm earnings. We thus contribute to the discussion of firm's agency costs stemming from the misalignment between control and ownership rights of ultimate shareholders (see e.g. Claessens et al. 2002). Fan and Wong (2002) show that due to the entrenchment effect, the credibility of the firm's accounting information is reduced which in turn lowers the stock price informativeness of the earnings. This loss of earnings credibility is thus increasing in the degree of divergence between the cash flow rights and voting rights (Francis et al., 2005). We extend previous works by providing evidence on the governance impact of MLS on nature and the strength of the relationship between accounting earnings and stock return. More precisely, considering the ownership and control divergence (or equivalently excess control), we analyze whether the presence of MLS may alleviate agency problems with minority shareholders thereby improving earnings informativeness.

Finally, we investigate the impact of shared control on the informativeness of the firm's earnings. Corporate governance literature agrees that the existence of large shareholders (beyond the largest controlling shareholder) can achieve a valuable internal monitoring function. Empirical studies find that the presence of multiple controlling shareholders might be value enhancing (Lehmann and Weigand, 2000; Volpin, 2002; Maury and Pajuste, 2005). Higher control contestability prevents opportunistic self-serving behavior thereby lessening minority expropriation (Gomes and Novaes, 2005), reduces the appropriation of private benefits of control (Bloch and Hege, 2001; Gutiérrez and Tribo, 2004), reduces rent extraction (Bennedson and Wolfenzon, 2000), enhances the value of firm's excess cash holdings (Laeven and Levine, 2008; Attig et al., 2009) and is associated with a lower cost of equity capital for firms (Guedhami and Mishra, 2009). We extent this line of research by identifying a channel through which high control contestability of the largest controlling shareholder (or equivalently the presence of MLS) might enhance a firm's information quality and thus greater earnings informativeness. 
Overall, our results consolidate the findings of who provide compelling evidence that control contestability may limit the negative effects associated with the presence of a single large shareholder, such as earnings manipulation and extraction of private benefits. More specifically, our study of how the presence of multiple large shareholders affects the informativeness of firms' accounting earnings generates several valuable insights. First, we find that earnings informativeness measured by the cumulative net-of-market 12-month stock returns (CAR), is significantly positively related to the ultimate cash flow rights. This evidence is consistent with the alignment effect whereby stock ownership aligns large shareholder's interests with those of minority shareholders, which in turn encourages transparency and reduces incentives to manipulate accounting information. We also find that earnings informativeness is significantly negatively related to the divergence between ultimate cash flow rights and control rights. This result is consistent with arguments advocating that excess control of the ultimate controlling shareholder is conducive to self-serving behavior (see e.g. Ball et al., 2003; Francis et al., 2005; Attig et al., 2006). Our result lends support to the entrenchment effect suggesting that controlling shareholders have greater incentives to obscure financial figures using, among other earnings management, untimely disclosure, etc., to hide their diversion activities when the expropriation likelihood is substantial (i.e. excess control is high). Our findings also show that the presence of multiple large shareholders and the contestability of control are related to significantly greater earnings informativeness. This result is consistent with the monitoring role of MLS and supports the findings of Bennendsen and Wolfenzon (2000), Gomes and Novaes (2005), Attig et al. (2008), and Guedhami and Mishra (2009). Indeed, we find that control contestability of the largest controlling shareholder mitigates information asymmetry problems thereby enhancing the informational environment of the firm.

The remainder of the paper is organized as follows. Section 2 details the development of our hypotheses. Section 3 describes data and sample selection procedure. Section 4 presents the methodology. Section 5 reports the empirical results. The penultimate section offers robustness checks and the last section concludes the paper.

\section{Development of hypotheses}

\subsection{Ultimate cash flow rights}

The effect of ownership structures on firm value has been extensively discussed. In publicly listed corporations, the separation between ownership and control may lead to conflicts of interest between financiers and managers who run the company (Fama and Jensen, 1983; Jensen and Meckling, 1976). These agency conflicts can be mitigated by monitoring. Investors with large ownership have strong incentives and enough control over the firm's assets to monitor the owner 
manager thereby pursuing firm's value maximization (Berle and Means, 1932; Demsetz and Lehn, 1985; Shleifer and Vishny, 1986; Admati et al., 1994). Faure-Grimaud and Gromb (2004) argue that large shareholders have incentives to engage in value-increasing activities since stock prices convey information to outsiders through public trading. Shareholders' incentives to pursue value-increasing activities translate in turn into higher firm valuation (Claessens et al., 2002). La Porta et al. (2002) also support the incentive effect by showing that higher cash flow ownership by the controlling shareholder increases firm value as measured by the Tobin's Q. Thus, large investors provide a solution to the free-rider problem (see e.g. Grossman and Hart, 1980; and Maug, 1998). Gomes (2000) argues that reputation concerns of the controlling shareholder plays as a credible commitment device not to expropriate minority shareholders. As ownership stakes increase the large shareholders' interests become aligned with those of small investors. In addition to high incentives to help overcome the conflicts of interest between shareholders and managers, large shareholders may coordinate their actions and put pressure on managers since voting power is not split among a highly segmented group of investors. Therefore, large ownership levels not only give incentive to decrease agency costs, but also the power to do so (Shleifer and Vishny, 1997; Kaplan and Minton, 1994). The presence of large controlling shareholders translates into strong incentives to monitor and discipline managers thereby replacing legal constraints on managerial opportunism (La Porta et al., 1999; Boubakri et al, 2005).

Drawing on the above arguments, we argue that large controlling shareholders have strong incentives to encourage management to report high quality earnings. Warfield et al (1995) focus on the incentive effects and find that earnings quality is generally increasing in the level of managerial ownership while the magnitude of discretionary accounting accrual adjustments decreases. Because stock ownership aligns management's interests with those of shareholders, this reduces or eliminates managers' incentives to manipulate accounting information. The relation between earnings informativeness and managerial ownership is not linear. The relation is increasing in small to medium levels of managerial ownership while decreasing in high levels of ownership (see e.g. Yeo et al., 2002). Studying a sample of Japanese firms, Yafeh and Yosha (2003) uncover evidence that large ownership levels are associated with lower discretionary spending. Extending their reasoning we expect that owning a large fraction of firm shares should increase earnings informativeness. The previous discussion provides an opportunity to further explore this relation through the following hypothesis:

Hypothesis 1: The informativeness of accounting earnings increases with the ultimate cash flow rights of the controlling shareholder. 


\subsection{Divergence between ownership and control}

The ownership structure of French listed companies is characterized by the presence of large controlling shareholders who possess more control than their equity ownership indicates. Control concentration enhanced beyond ownership stakes may depart the interests of controlling shareholders from those of minority investors (see e.g. La Porta et al., 2000). Extensive research documents that excess control built through dual-class shares, pyramidal structures or cross-holding among firms enables controlling shareholders to accrue private benefits thereby expropriating minority shareholders (La Porta et al., 1999; Claessens et al., 2000; Bertrand et al., 2002; Faccio and Lang, 2002). As such, the contest to the control of the dominant shareholders stems from the conflict between controlling and non-controlling shareholders (Ali et al., 2007).

The likelihood of minority shareholder expropriation is particularly high if large investors hold voting rights in excess of cash flow rights (Faccio et al., 2001). In these cases, they have an incentive to pay out a larger proportion of company cash flows to themselves instead of evenly distributing funds among all shareholders. Francis et al. (2005) find that earnings in dual class firms (i.e. firms characterized a separation of cash flow rights from voting rights) are less informative than earnings in single class firms, suggesting that the separation of control right and ownership is negatively related to informativeness of accounting earnings. Fan and Wong (2002) argue that East Asian firms with a discrepancy between voting rights and cash flow rights are perceived to provide controlling shareholders incentives to take self-interested actions causing the reported earnings to lose credibility to outside investors. In other words, there is a credibility-reducing effect of entrenchment which is increasing in the degree of divergence between cash flow rights and voting rights. Evidence on the effect of the divergence between ownership and control is provided, among many others, by Claessens et al. (2002). Studying East Asian economies, they find a positive and significant relationship between the cash flow ownership of the largest shareholder and firm value and interpret this result as a positive incentive effect of large shareholdings. In light of the above arguments, we draw the following hypothesis:

Hypothesis 2: Earnings informativeness decreases with the separation between ultimate cash flow rights and control rights.

\subsection{Multiple controlling shareholders}

Private benefits of control imply conflicts of interests that might be alleviated by relying on mechanisms capable of protecting the rights of minority shareholders. A large body of literature has emphasized the monitoring role that may be played by outside shareholders (see e.g., Shleifer and 
Vishny, 1986; Kahn and Winton, 1998; Bloch and Hege, 2001; and Noe, 2002). Outside investors may lack incentives to monitor controlling owners, since they would bear all the monitoring costs but capture only a small portion of the monitoring gains (see Grossman and Hart, 1980). Burkart et al. (1997) and Bolton and Von Thadden (1998) argue, however, that outside investors have incentives to increase the liquidity costs without offering compensating advantages in monitoring, due to shareholders liquidity-control trade-off. Because the monitoring of investment decisions by outside investors fails to solve conflicts of interest, related themes of multiple large shareholders have also been visited as alternative mechanisms that may protect minority shareholders. More specifically, an ownership structure with multiple controlling shareholders may play as a commitment device that allows reaching an optimal monitoring intensity (Pagano and Röell, 1998). The presence of several large shareholders may then be associated with valuable monitoring, in particular when their share investments are evenly distributed. In other words, multiple blocks commit the firm to protect minority investors. Yet, a number of papers argue that multiple blockholders are unlikely to emerge. In Zwiebel's (1995) general equilibrium model, investors are sorting such that only one of them holds a block in any given firm, precisely because they want to eschew the sort of competition over benefits. Winton (1993) emphasizes the free-rider problem in monitoring efforts among multiple large shareholders.

Contrariwise, some authors contend that the presence of multiple large shareholders may ensure the eschewal of expropriation. In a context where multiple large shareholders compete to gather minority votes as the latter is pivotal to seize control, Bennedsen and Wolfenzon (2000) show that it is optimal to have as much shareholders as possible in a controlling coalition. This coalition with the lowest possible cash flow stake will have the largest group of non-controlling shareholders from whom to expropriate which is considered as a bad outcome in terms of efficiency. Furthermore, the greater the cash flow possessed by this coalition, the more the coalition internalizes the costs of private benefits extraction and imposes limits on minority expropriation. Gomes and Novaes (2005) consider the trade-off that may exist between an inefficient monitoring of outside investors and the bargaining costs associated with the existence of multiple controlling shareholders. Their theoretical model allows solving this trade-off and shows that sharing control among large shareholders may increase efficiency in firms with investment opportunities that are hard to evaluate by outsiders. The presence of multiple large shareholders is seen as a device capable of limiting rent extraction, and securing the vote of minority shareholders when the different large shareholders' shares are fairly similar (Bloch and Hege, 2001). Hence, all large shareholders perform a monitoring role and compete for the votes of minority shareholders by committing to reduce their private benefits. 
In line with these arguments, empirical studies were conducted to derive evidence on the impact of the presence of multiple large shareholders. Zwiebel (1995) considers a setting in which ownership structure is defined by shareholders who allocate their wealth across firms in order to receive a larger share of private benefits and shows that the control benefits will be divided among the multiple large shareholders depending on the relative size of their respective shares. Maury and Pajuste (2005) argue that the presence of several large shareholders should have a positive effect on minority investors and firm's efficiency. Contestability of the controlling coalition's power might increase firm value and limit the expropriation of minority shareholders. Moreover, the marginal cost of stealing increases with the number of coalition partners thereby discouraging the extraction of private benefits and diversion of profits. Indeed, high control contestability of the largest controlling shareholder might enhance a firm's information quality and thus greater earnings informativeness. This result is consolidated by the findings of Attig et al. (2009) who provide compelling evidence that the distribution of control rights among multiple large shareholders alleviate agency costs of firm's liquid assets. Their results indicate that an increase in the contestability of the largest controlling shareholder's control —as a result of the higher relative voting power of the second and third largest shareholders or the pivotal voting power of the minority interests - may enhance the value of firm's excess cash holdings, since it will be harder to convert liquid assets into private benefits. In line with Laeven and Levine (2008), this result indicates that a firm with uneven distribution of voting rights among the controlling shareholders is likely to have more serious agency problems that may lead to cash diversion. In turn, the existence of large shareholders (beyond the largest controlling shareholder) can achieve valuable internal monitoring (Guedhami and Mishra, 2009). Attig et al. (2008) document that when other large shareholders intervene in the preparation of financial information concealing or manipulating earnings by the largest shareholder becomes costly and more difficult. A high control contestability of the largest controlling shareholder is then a device to protect minority shareholders plausibly because it alleviates the diversion of firm's resources for private benefits. The intuition behind this result is similar to that in Gutiérrez and Tribo (2004) who find that the presence of more than one controlling shareholder substantially decreases private benefit extraction because of the bargaining problem that occurs among large shareholders who are forced to share control.

Overall, control contestability may downgrade the negative effects of a single large shareholder, such as the presence of earnings manipulation, low disclosure quality and extraction of private benefits. Based on these arguments we propose the following hypothesis:

Hypothesis 3: Earnings informativeness increases when control is contestable. 


\section{Data Sources and sample selection procedure}

The initial sample is restricted to all French firms available in the Worldscope database for the 2003-2007 period. Following previous studies, we remove regulated utilities (SIC code 49004999) and financial firms (SIC code 6000-6999) due to the specificities of their informational environment which is more likely to be affected by legal and regulatory motives rather than by agency concerns. We discard all unlisted firms, those listed since less than one year and those with incomplete financial and/or return data. We also exclude firms for which we were unable, due to missing ownership data, to trace control chains back to the ultimate controlling owners. Applying the above-mentioned criteria, we were left with a sample of 402 firms corresponding to 2,384 firmyear observations (See Table 1, for detailed definition of all variables used in the analysis and Table 2 for more details on sample selection criteria and on distribution of firms on a year-by-year basis). Financial data and stock price related data are retrieved from the databases Worldscope and Datastream, respectively. Data on ownership structures were excerpted from firms' annual reports which provide the list of all shareholders with more than five percent of the ownership or voting stake. Annual reports are available from the AMF's website (Autorité des Marchés Financiers).

\section{Methodology}

\subsection{The effect of ownership structure}

To test the effect of multiple large shareholders on earnings informativeness, we adopt the following regression model:

$$
\begin{aligned}
& C A R_{i t}=\alpha_{0}+\alpha_{1}\left(N I_{i t}\right)+\alpha_{2}\left(N I_{i t} * U C F_{i t}\right)+\alpha_{3}\left(N I_{i t} * \text { Excess Control }{ }_{i t}\right)+\alpha_{4}\left(N I_{i t} * M L S \text { Variables }_{i t}\right) \\
& +\alpha_{5}\left(N I_{i t} * \text { Firm Size }_{i t}\right)+\alpha_{6}\left(N I_{i t} * Q_{i t}\right)+\alpha_{7}\left(N I_{i t} * \text { Leverage }_{i t}\right)+\alpha_{8}\left(N I_{i t} *\right. \text { Industry } \\
& \text { diversification } \left._{i t}\right)+(\text { Fixed Effects })+\varepsilon_{i t}
\end{aligned}
$$

where, for sample firm $i, C A R_{i t}$ is the cumulative net-of-market 12-month stock returns ending at the fiscal year-end $\mathrm{t}$ (winsorized at 1st and 99th percentile); $N I_{i t}$ is the net earnings at the end of the fiscal year $t$ scaled by the market value of equity at the beginning of the fiscal year $t$ (winsorized at 1 st and 99th percentile); $U C F$ is the ultimate cash flow rights at the $10 \%$ threshold. It is measured as the sum of products of direct cash flow rights along the different ownership chain; Excess Control is a proxy for the separation between ultimate cash flow and control rights. It is computed as the difference between the ultimate control stake $(U C O)$ and the ultimate cash flow stake $(U C F)$, all divided by the ultimate control stake $((U C O-U C F) / U C O)$. UCO is the ultimate control rights at 
the $10 \%$ threshold. It is the sum of weakest links along the different control chains. MLS Variables are various proxies for the presence and relative voting power of large controlling shareholders beyond the dominant owner. They are included one at once depending on the specification. Among the MLS Variables we include the following measures. First, $M L D S$ is the multiple large shareholder dummy variable. It equals one if there are at least two large shareholders who hold each more than $10 \%$ of the control rights, and zero otherwise. Second, VOTE21 is the ratio of control rights of the second largest shareholder to control rights of the largest shareholder, VOTE2/VOTE1.

\section{Table 1}

\section{Definitions and sources of variables}

\begin{tabular}{|c|c|c|}
\hline Variable & Definition & Source \\
\hline CAR & $\begin{array}{l}\text { The cumulative net-of-market } 12 \text {-month stock returns. The annual returns } \\
\text { are continuously compounded from weekly stock returns starting from } 52 \\
\text { weeks ( } 12 \text { months) before the latest date that the firm discloses its annual } \\
\text { report. }\end{array}$ & Datastream \\
\hline NI & $\begin{array}{l}\text { The net earnings at year } \mathrm{t} \text { divided by the market value of equity at the } \\
\text { beginning of the fiscal year. }\end{array}$ & Wordscope \\
\hline $\mathrm{UCF}$ & $\begin{array}{l}\text { Ultimate Cash Flow rights (at the } 10 \% \text { threshold): the sum of the products of } \\
\text { direct cash flow rights along the different ownership chains. }\end{array}$ & $\begin{array}{l}\text { Authors' calculations } \\
\text { based on annual reports }\end{array}$ \\
\hline Excess control & $\begin{array}{l}\text { Excess Control (at the } 10 \% \text { threshold) is the difference between the LCS's } \\
\text { ultimate control rights (UCO) and ultimate cash flow rights (UCF), all } \\
\text { divided by his/her ultimate control rights (UCO) (i.e., (UCO - UCF) / } \\
\text { UCO). UCO is the sum of the weakest links along the different control } \\
\text { chains (at the } 10 \% \text { threshold) }\end{array}$ & As above \\
\hline MLSD & $\begin{array}{l}\text { Multiple large shareholder dummy variable equals one if there are at least } \\
\text { two large shareholders who hold each more than } 10 \% \text { of the control rights, } \\
\text { and zero otherwise. }\end{array}$ & As above \\
\hline VOTE21 & $\begin{array}{l}\text { Ratio of control rights of the second largest shareholder to control rights of } \\
\text { the largest shareholder, VOTE2/ VOTE1. }\end{array}$ & As above \\
\hline VOTE231 & $\begin{array}{l}\text { Ratio of voting rights of the second and third largest shareholders to voting } \\
\text { rights of the largest shareholder, (VOTE2+ VOTE3)/ VOTE1. }\end{array}$ & As above \\
\hline HERFDVOTE & $\begin{array}{l}\text { The natural logarithm of the Herfindhal index of the differences in the } \\
\text { voting rights of two successive large shareholders, (VOTE1- } \\
\text { VOTE2) })^{2}+(\text { VOTE2- VOTE } 3)^{2} \text {. }\end{array}$ & As above \\
\hline SIZE & $\begin{array}{l}\text { The natural logarithm of the market value of equity }(\ln (\mathrm{MVE})) \text { in millions of } \\
\text { Euros at the beginning of the fiscal year. }\end{array}$ & Wordscope \\
\hline Q & $\begin{array}{l}\text { The market value of equity divided by the book value of total assets at the } \\
\text { beginning of the fiscal year. }\end{array}$ & As above \\
\hline Leverage & Total liability divided by total assets at the beginning of the fiscal year. & As above \\
\hline $\begin{array}{l}\text { Industry } \\
\text { diversification }\end{array}$ & $\begin{array}{l}\text { Number of distinct business segment(s) at the two-digit SIC code level in } \\
\text { which the firm operates. }\end{array}$ & As above \\
\hline Industry dummies & Industry dummies following Campbell's (1996) classification. & As above \\
\hline
\end{tabular}

Third, VOTE231 is the ratio of voting rights of the second and third largest shareholders to voting rights of the largest shareholder, (VOTE2+VOTE3)/VOTE1. Finally, HERFDVOTE is the Herfindhal index of the differences in the voting rights of two successive large shareholders, $(\text { VOTE1-VOTE2 })^{2}+(\text { VOTE2-VOTE3 })^{2}$. 
Table 2

\section{Sample selection criteria of French listed firms}

\begin{tabular}{|c|c|}
\hline \multicolumn{2}{|l|}{ Panel A: Number of firm-years by sample selection criteria } \\
\hline Selection criteria & Number of firm-years \\
\hline French firms available in the Wordscope database for the $2003-2007$ period & 4580 \\
\hline $\begin{array}{l}\text { Less financial firms (SIC code 6000-6999) and regulated utilities } \\
\text { (SIC code 4900-4999) }\end{array}$ & 513 \\
\hline Less unlisted firms and firms listed since less than one year & 198 \\
\hline Less firms with missing return data & 428 \\
\hline Less firms with missing financial data & 306 \\
\hline Less firms with missing or incomplete ownership and voting data & 751 \\
\hline Total firms included in the sample & 2384 \\
\hline \multicolumn{2}{|l|}{ Panel B: Number of sample firms by year } \\
\hline Year & Number of firms \\
\hline 2003 & 501 \\
\hline 2004 & 474 \\
\hline 2005 & 460 \\
\hline 2006 & 469 \\
\hline 2007 & 480 \\
\hline Total & 2384 \\
\hline
\end{tabular}

We introduce a set of variables as surrogates of firm characteristics to control for observed variations in the relation between earnings and returns that are likely due to causes other than those related to firm ownership structure. We rely on previous research in considering the following variables that may affect firms' earnings informativeness. Firm size was found by Bamber (1987) and Freeman (1987) to be positively associated with the informational content of earnings announcements. We include it in our regressions to control for its potential effect on earnings informativeness. One explanation for this positive association is that large firms have more informative security prices due to more timely, alternative information being available as compared to small firms (Atiase, 1985). Thus, we include the natural logarithm of the market value of equity in millions Euros at the beginning of the fiscal year t (Firm size) to control for the effects of firm size on the earnings-return relation.

We also use, $Q$, the ratio of the market value of equity divided by the book value of total assets at the beginning of the fiscal year $\mathrm{t}$ (winsorized at 1st and 99th percentile) to control for the impact of growth prospects on the earnings-return relation. This effect is ambiguous at least theoretically. On the one hand, high company growth opportunity translates into larger expected earnings growth. As investors stock price responses towards current earnings is significant, the stock price informativeness of firms' earnings increases. On the other hand, the market-to-book ratio is tied to firm risk. The risk associated with high growth firms and/or fast growing firms may translate into less informative earnings. Empirically, Collins and Kothari (1989) show a positive relation between investment opportunities and earnings transparency. Smith and Watts (1992) show that the issuance of diluted securities is more frequent in firms with higher growth opportunities hence earnings information will be impounded better on the firm's stock prices. 
We also include Leverage as a control for firms' default risk. Leverage negatively impacts bond assessment (Dhaliwal and Reynolds, 1994) and earnings informativeness (Billings, 1999). Therefore, we expect that highly levered firms have less informative earnings. Leverage is measured as the ratio of the book value of total liabilities divided by the book value of total assets at the beginning of the fiscal year $t$.

Finally, we include Industry diversification as the number of distinct business segments at the two-digit SIC code level in which the sampled firm operates. Prior studies show that a company's industry diversification has a detrimental effect on financial analysts' ability to forecast earnings (Denis et al., 1997). Hence, a company's unrelated and related industry diversification may have negative impact on earnings informativeness.

Table 3 analyzes the identity of the controlling shareholders of French listed firms depending on whether the control is maintained by one or multiple controlling shareholders. The results show that concentrated ownership is a ubiquitous feature of these firms. Only $6 \%$ of the French listed firms do not exhibit a controlling shareholder at a control threshold of $10 \%$. Following previous relevant literature, we categorize ultimate owners into five classes namely (1) family; (2) widely held firm; (3) widely held financial institution; (4) State; and (5) miscellaneous (i.e., a charity, a cooperative, employees, etc.). As a result, we find that family firms dominate the corporate landscape in France $(83.31 \%)$. The State, widely held corporations and widely held financial institutions control only $4.51 \%, 3.53 \%$ and $4.77 \%$ of the French listed firms, respectively. Multiple large shareholders are fairly common (44.89\% of controlled listed firms). They are more present in firms controlled by widely held financial institutions $(67.29 \%)$ and by widely held firms $(55.70 \%)$ than in family firms $(43.06 \%)$ and in state-owned firms $(43.56 \%)$.

\section{Table 3}

\section{Sample characteristics}

\begin{tabular}{|c|c|c|c|c|c|c|}
\hline & \multicolumn{2}{|c|}{$\begin{array}{l}\text { All sample firms } \\
(2384)\end{array}$} & \multicolumn{2}{|c|}{$\begin{array}{l}\text { MLS firms } \\
(1006)\end{array}$} & \multicolumn{2}{|c|}{$\begin{array}{c}\text { Non MLS firms } \\
(1235)\end{array}$} \\
\hline & Number & Percentage & Number & Percentage & Number & Percentage \\
\hline Widely held firms & 143 & $6.00 \%$ & & & & \\
\hline Controlled firms & 2241 & $94.00 \%$ & 1006 & $44.89 \%$ & 1235 & $55.11 \%$ \\
\hline All sampled firms & 2384 & $100.00 \%$ & & & & \\
\hline \multicolumn{3}{|c|}{ Identity of the ultimate controlling shareholder } & Number & $\begin{array}{l}\text { Percentage } \\
\text { within class }\end{array}$ & Number & $\begin{array}{l}\text { Percentage } \\
\text { within class }\end{array}$ \\
\hline Family-controlled firms & 1867 & $83.31 \%$ & 804 & $43.06 \%$ & 1063 & $56.94 \%$ \\
\hline State controlled firms & 101 & $4.51 \%$ & 44 & $43.56 \%$ & 57 & $56.44 \%$ \\
\hline $\begin{array}{l}\text { Widely held corporation } \\
\text { Controlled firms }\end{array}$ & 79 & $3.53 \%$ & 44 & $55.70 \%$ & 35 & $44.30 \%$ \\
\hline $\begin{array}{l}\text { Widely held financial institution } \\
\text { controlled firms }\end{array}$ & 107 & $4.77 \%$ & 72 & $67.29 \%$ & 35 & $32.71 \%$ \\
\hline Miscellaneous & 87 & $3.88 \%$ & 42 & $48.28 \%$ & 45 & $51.72 \%$ \\
\hline Total of controlled firms & 2241 & $100.00 \%$ & 1006 & $51.80 \%$ & 1235 & $42.20 \%$ \\
\hline
\end{tabular}


Table 4 provides summary statistics of all variables used in the empirical analysis. The CAR and NI present both large dispersion across sampled firms with a median value of $-5.41 \%$ and $5.49 \%$, respectively. Summary statistics of ownership variables are in accordance with those provided by Faccio and Lang (2002) and Boubaker (2007). They show that the control of French firms is often ensured through a relatively small proportion of cash flow rights compared to that of control rights. In fact, ultimate controlling owners hold, on average, $41.00 \%$ of the ultimate cash flow rights and also control significantly more control rights than those determined by their corresponding ownership stakes leading to an average excess control of $21.24 \%$. This separation between ultimate cash flow rights and control rights is prevalent in roughly $81.08 \%$ of the sampled firms (1933 firm-year observations). The voting power of the largest controlling shareholder is, on average, four times higher than that of the second largest shareholders (VOTE21 = 25\%). The Herfindahl index measures the dispersion of voting rights among main large shareholders. It shows, as other MLS proxies, systematic differences across sampled firms and ranges from a minimum of 0 (equal voting power between largest shareholders) to a maximum of $98 \%$ (one dominant shareholder). Firms that have more than one significant shareholder $(M L S D=1)$ represent $42.20 \%$ of the sampled firms (1006 firmyear observations). Regarding size and leverage, firms vary from small-sized $(\ln (\mathrm{MVE})=3.34)$ to large-sized $(\ln (\mathrm{MVE})=18.99)$ and from unleveraged (Leverage $=0.00 \%)$ to highly leveraged (Leverage $=97.91 \%$ ). The median value of $\mathrm{Q}$ equals 0.72 suggesting that more than half of the sampled firms destroy value. As for the degree of industry diversification, the mean (median) of diversification is 2.82 (2), suggesting that on average French firms operate in three industries. Sample firms present different degrees of diversification, from specialized firms (singe-industry firms) to highly diversified firms. Note that we have winsorized variables whose values do not vary within reasonable ranges to avoid that our estimates will be unduly influenced by outlier observations.

\section{Table 4}

\section{Summary statistics of regression variables}

\begin{tabular}{|c|c|c|c|c|c|c|c|}
\hline & Minimum & $\begin{array}{c}\text { First } \\
\text { quartile }\end{array}$ & Median & Mean & $\begin{array}{c}\text { Third } \\
\text { quartile }\end{array}$ & Maximum. & Std. Dev. \\
\hline CAR (\%) & -103.33 & -26.18 & -5.41 & -4.25 & 14.80 & 110.55 & 39.09 \\
\hline$N I(\%)$ & -462.30 & 0.72 & 5.49 & -0.18 & 9.03 & 426.98 & 48.18 \\
\hline \multicolumn{8}{|c|}{ LCS related variables } \\
\hline$U C F(\%)$ & 0.30 & 19.71 & 39.52 & 41.00 & 60.31 & 99.49 & 25.15 \\
\hline Excess control (\%) & -29.48 & 2.30 & 18.08 & 21.24 & 32.53 & 96.47 & 20.87 \\
\hline \multicolumn{8}{|c|}{$M L S$ related variables } \\
\hline$M L S D$ & 0.00 & 0.00 & 0.00 & 0.42 & 1 & 1 & 0.49 \\
\hline VOTE21 & 0.00 & 0.00 & 0.42 & 0.25 & 0.45 & 1.00 & 0.35 \\
\hline VOTE231 & 0.00 & 0.00 & 0.15 & 0.37 & 0.64 & 2.00 & 0.46 \\
\hline HERFDVOTE & 0.00 & 0.05 & 0.19 & 0.28 & 0.46 & 0.98 & 0.26 \\
\hline \multicolumn{8}{|l|}{ Control variables } \\
\hline Firm size & 3.34 & 10.44 & 11.68 & 12.05 & 13.28 & 18.99 & 2.22 \\
\hline$Q$ & 0.004 & 0.40 & 0.72 & 1.22 & 1.32 & 20.86 & 2.09 \\
\hline Leverage (\%) & 0.00 & 49.39 & 64.62 & 82.63 & 80.41 & 97.91 & 2.05 \\
\hline $\begin{array}{l}\text { Industry } \\
\text { Diversification }\end{array}$ & 1 & 2 & 2 & 2.82 & 4 & 8 & 1.50 \\
\hline
\end{tabular}




\subsection{Basic regression}

As a starting point, we first estimate a basic simple linear regression model that relates earnings to stock returns in France:

$$
C A R_{i t}=\alpha_{0}+\alpha_{1}\left(N I_{i t}\right)+(\text { Industry dummies })+\varepsilon_{i t}
$$

where, the $\mathrm{CAR}_{\mathrm{it}}$ is the cumulative net-of-market 12-month stock returns ending at the fiscal year-end t. The annual returns are continuously compounded from weekly stock returns starting from 52 weeks (12 months) before the latest date that the firm discloses its annual report; $\mathrm{NI}_{\mathrm{it}}$ is the net earnings at the end of the fiscal year $t$ scaled by the market value of equity at the beginning of the fiscal year t. Both variables are winsorized at 1st and 99th percentile. Industry dummies are constructed following Campbell's (1996) classification. $\varepsilon_{\mathrm{it}}$ the error term at year t. Similar to prior research, the ordinary least squares regression results show that the estimated coefficients of earnings are positive and statistically significant at a $1 \%$ threshold level irrespective of whether the equation is estimated on a year by year basis or on the pooled sample of all years from 2003 to 2007. This implies that earnings have substantial informational content for French listed firms (See, Table 5).

\section{Empirical results}

\subsection{The largest controlling shareholder and earnings informativeness}

Following in the footsteps of Claessens et al. (2002), we include ultimate cash flow rights $(U C F)$ in all regressions to control for the incentive alignment effect of the largest shareholder and ultimate control rights in excess of cash flow rights (Excess Control) as to control for the extent of his/her entrenchment. Consistent with Hypotheses 1 and 2, the coefficients on UCF $\left(\alpha_{2}\right)$ and on Excess Control $\left(\alpha_{3}\right)$ are expected to be significantly different from zero. A positive estimate on $\alpha_{2}$ will be evidence that a higher interest stake of the largest controlling shareholder is associated with more informative earnings which is consistent with the incentive effect. A negative estimate on $\alpha_{3}$ will provide evidence that the earnings of firms exhibiting larger separation between ultimate cash flow rights and control rights are less informative that others. The empirical results are portrayed in Table 6 . The coefficient estimates are from the pooled ordinary least squares regressions using the $C A R$ as the dependent variable where the t-statistics are based on standard errors with White (1980) correction for heteroscedasticity and adjusted for clustering for observations at the firm level. In conformity with the first hypothesis, the coefficient $U C F$ is positive and statistically significant at $1 \%$ confidence level. This suggests that higher cash flow stakes of the large controlling shareholder are associated with more convergence between his/her interests with those of minority shareholders. Large shareholders are more inclined to opt for higher financial reporting quality and for more 
disclosure of material information in a timely and convenient manner which leads to greater informativeness of accounting earnings.

Consistent with our second hypothesis and in accordance with the entrenchment effect argument, the coefficient of Excess control is negative and statistically significant at the $1 \%$ confidence level. Higher separation between cash flow rights and control rights makes the market expect more entrenchment of the controlling shareholder who may prefer to establish delayed or misleading disclosure practices that hide his/her potential expropriation activities. This market perception reduces reliance on accounting earnings reports which weakens earnings informativeness.

Overall, results provide strong evidence that earnings are more informative in firms where ultimate owners hold large cash flow rights and less informative when cash flow right are separated from control rights which supports our first two hypotheses. All specifications in Table 6 are significant at least at 0.001 level. The adjusted $\mathrm{R}^{2}$ values are about 0.07 and are comparable with those of relevant studies.

\section{Table 5}

Year-by-year regressions of stock returns on earnings

\begin{tabular}{|c|c|c|c|c|c|}
\hline & Intercept & NI & Adjusted $\mathrm{R}^{2}$ & F de Fisher & $\begin{array}{l}\text { Number of } \\
\text { observations }\end{array}$ \\
\hline \multirow[t]{2}{*}{2003} & -0.1284 & 0.1460 & $7.82 \%$ & $4.86^{\mathrm{a}}$ & 501 \\
\hline & $(-1.8486)^{\mathrm{c}}$ & $(5.5756)^{\mathrm{a}}$ & & & \\
\hline \multirow[t]{2}{*}{2004} & -0.0500 & 0.1678 & $6.94 \%$ & $3.13^{\mathrm{a}}$ & 474 \\
\hline & $(-0.6765)$ & $(4.9656)^{\mathrm{a}}$ & & & \\
\hline \multirow[t]{2}{*}{2005} & -0.1110 & 0.2121 & $5.02 \%$ & $3.20^{\mathrm{a}}$ & 460 \\
\hline & $(-1.5749)$ & $(4.6102)^{\mathrm{a}}$ & & & \\
\hline \multirow[t]{2}{*}{2006} & -0.0373 & 0.1199 & $3.18 \%$ & $3.27^{\mathrm{a}}$ & 469 \\
\hline & $(-2.2114)^{b}$ & $(2.7064)^{\mathrm{a}}$ & & & \\
\hline \multirow[t]{2}{*}{2007} & -0.0363 & 0.2977 & $4.65 \%$ & $3.12^{\mathrm{a}}$ & 480 \\
\hline & $(-2.1179)^{\mathrm{b}}$ & $(4.9137)^{\mathrm{a}}$ & & & \\
\hline \multirow[t]{2}{*}{ Pooled observations } & -0.0605 & 0.1573 & $4.08 \%$ & $3.76^{\mathrm{a}}$ & 2384 \\
\hline & $(-2.1573)^{b}$ & $(4.8647)^{\mathrm{a}}$ & & & \\
\hline
\end{tabular}

This table presents the results of the estimation of the following model: $\mathrm{CAR}_{\mathrm{it}}=\alpha_{0}+\alpha_{1}\left(\mathrm{NI}_{\mathrm{it}}\right)+($ industry dummies$)+\varepsilon_{\mathrm{it}}$. The $\mathrm{t}-$ statistics, based on the White's heteroscedasticity-consistent robust standard errors, are between parentheses below the estimated coefficients. The last regression uses all observations (pooled) and controls for clustering at the firm level. The symbols a, b and c denote statistical significance at the $1 \%, 5 \%$ and $10 \%$ level, respectively.

The effects of growth opportunities on the relation between accounting earnings and market returns are controlled through the use of $Q$. The coefficient on this variable is positive indicating that higher growth potentials strengthen the earnings-return relation which is consistent with Jung and Kwon (2002). Leverage is negatively associated with earnings informativeness. High leverage often implies higher likelihood of default risk suggesting loosely relationship between return and 
earnings. The coefficient on Industry diversification is negative suggesting that earnings are more informative in focused than in diversified firms. One possible explanation is that earnings in focused firms are generated through a relatively less complex process. Firm size, proxied by the natural logarithm of the market value of equity, does not seem to affect the extent of earnings informativeness in France.

\subsection{Multiple controlling shareholders and earnings informativeness}

The main focus of this study is to investigate the impact of multiple large shareholders on the informativeness of the firms' earnings. To the extent that multiple controlling shareholders play an efficient-monitoring role and limit the agency costs associated with the presence of a dominant owner, we expect that earnings informativeness increases with the presence of more than one controlling shareholder $(\mathrm{MLSD}=1)$, when the power of the remaining large shareholders (Vote21 and Vote231) is substantial and when the concentration of differences in voting rights of two successive large shareholders (Herfdvote) is low.

\section{Table 6}

\section{Multiple large shareholders and earnings informativeness}

\begin{tabular}{|c|c|c|c|c|c|c|c|c|}
\hline \multirow[b]{2}{*}{ Variables } & \multicolumn{2}{|c|}{$\begin{array}{c}\text { Specification } 1 \\
\text { MLSD }\end{array}$} & \multicolumn{2}{|c|}{$\begin{array}{c}\text { Specification } 2 \\
\text { VOTE21 }\end{array}$} & \multicolumn{2}{|c|}{$\begin{array}{c}\text { Specification } 3 \\
\text { VOTE231 }\end{array}$} & \multicolumn{2}{|c|}{$\begin{array}{l}\text { Specification } 4 \\
\text { HERFDVOTE }\end{array}$} \\
\hline & Coef. & $t$-value & Coef. & $t$-value & Coef. & $t$-value & Coef. & $t$-value \\
\hline $\mathrm{NI}$ & $0.1590^{\mathrm{b}}$ & $(2.5307)$ & $0.1535^{\mathrm{b}}$ & $(2.4198)$ & $0.1619^{\mathrm{b}}$ & $(2.3453)$ & $0.2457^{\mathrm{a}}$ & $(4.6503)$ \\
\hline NI*UCF & $0.0582^{\mathrm{a}}$ & $(5.6641)$ & $0.0554^{\mathrm{a}}$ & $(5.1643)$ & $0.0573^{\mathrm{a}}$ & (4.6744) & $0.0687^{\mathrm{a}}$ & $(5.3637)$ \\
\hline NI*Excess control & $-0.0791^{\mathrm{a}}$ & $(-9.6302)$ & $-0.0764^{\mathrm{a}}$ & $(-8.6746)$ & $-0.0749^{\mathrm{a}}$ & $(-8.1587)$ & $-0.0648^{\mathrm{a}}$ & $(-6.1455)$ \\
\hline NI*MLSD & $0.1149^{\mathrm{a}}$ & $(3.0822)$ & & & & & & \\
\hline NI*VOTE21 & & & $0.1989^{\mathrm{a}}$ & $(2.9919)$ & & & & \\
\hline NI*VOTE231 & & & & & $0.1085^{\mathrm{b}}$ & $(2.0072)$ & & \\
\hline NI*HERFDVOTE & & & & & & & $-0.2669^{\mathrm{a}}$ & $(-2.7712)$ \\
\hline \multicolumn{9}{|l|}{ Control Variables } \\
\hline NI*Firm size & 0.0022 & $(0.6727)$ & 0.0003 & $(0.1264)$ & 0.0001 & $(0.0155)$ & 0.0040 & $(1.2993)$ \\
\hline $\mathrm{NI} * \mathrm{Q}$ & $0.0010^{\mathrm{b}}$ & $(2.0348)$ & $0.0003^{\mathrm{b}}$ & $(2.1248)$ & $0.0004^{\mathrm{b}}$ & $(2.1483)$ & $0.0006^{\mathrm{b}}$ & $(2.2136)$ \\
\hline NI*Leverage & $-0.0023^{\mathrm{a}}$ & $(-2.6982)$ & $-0.0009^{b}$ & $(-2.0158)$ & $-0.0010^{c}$ & $(1.8486)$ & $-0.0013^{\mathrm{b}}$ & $(-2.4436)$ \\
\hline $\begin{array}{l}\text { NI*Industry } \\
\text { diversification }\end{array}$ & $-0.0181^{\mathrm{b}}$ & $(-2.4821)$ & $-0.0091^{\mathrm{b}}$ & $(-2.0956)$ & $-0.0079^{b}$ & $(-2.0467)$ & $-0.0152^{\mathrm{b}}$ & $(-2.1754)$ \\
\hline Industry dummies & \multicolumn{2}{|c|}{ YES } & \multicolumn{2}{|c|}{ YES } & \multicolumn{2}{|c|}{ YES } & \multicolumn{2}{|c|}{ YES } \\
\hline Constant & $-0.0490^{c}$ & $(-1.7527)$ & $-0.0537^{\mathrm{c}}$ & $(-1.9333)$ & $-0.0562^{\mathrm{b}}$ & $(-2.0181)$ & $-0.0536^{\mathrm{c}}$ & $(-1.9346)$ \\
\hline F-Value & \multicolumn{2}{|c|}{$13.83^{\mathrm{a}}$} & \multicolumn{2}{|c|}{$16.75^{\mathrm{a}}$} & \multicolumn{2}{|c|}{$13.58^{\mathrm{a}}$} & \multicolumn{2}{|c|}{$15.96^{\mathrm{a}}$} \\
\hline Adjusted $R$-squared & \multicolumn{2}{|c|}{$7.31 \%$} & \multicolumn{2}{|c|}{$7.18 \%$} & \multicolumn{2}{|c|}{$6.87 \%$} & \multicolumn{2}{|c|}{$7.03 \%$} \\
\hline Number of & \multicolumn{2}{|c|}{2384} & \multicolumn{2}{|c|}{2384} & \multicolumn{2}{|c|}{2384} & \multicolumn{2}{|c|}{2384} \\
\hline
\end{tabular}

Table 6 estimates the parameters of the pooled time-series cross-section regression model of multiple large shareholders on earnings informativeness. The dependent variable is earnings informativeness proxied by the cumulative net-of-market 12-month stock returns (CAR). See Table 1 for the definition if the remaining variables. The t-statistics are based standard errors with White (1980) correction for heteroscedasticity and adjusted for clustering for observations at the firm level. The symbols a, b and $\mathrm{c}$ denote statistical significance at the $1 \%, 5 \%$ and $10 \%$ level, respectively. 
Lower values of Herfdvote correspond to situations where controlling shareholders have comparable voting stakes. We expect that more contestable control (i.e., lower Herfdvote) reduces the likelihood of private benefits extraction, increases the commitment to a more consistent disclosure policy and thereby enhances the informative content of firm earnings.

Table 6 displays regression results of multivariate regression with MLS-related proxies as independent variables and the $C A R$ as the dependent variable. The coefficient on net income (NI) in specification 1 (Table 6) is 0.1590 and significant at $\mathrm{p}<0.05$. The coefficient on our key test variable $\left(N I^{*} M L S D\right)$ is 0.1149 with a p-value less than 0.01 . This suggests that, on average, the earning response coefficient of firms with multiple large shareholders is $72.26 \%(0.1149 / 0.1590=$ 0.7226) higher than that for firms controlled by a unique large shareholder. This result is economically significant using the $10 \%$ rule of thumb for materiality. MLS seem to play an important governance role in limiting rent-seeking behavior. Their presence enhances the quality of accounting earnings and increases confidence on reported figures which in turns strengthens the relationship between stock prices and accounting of earnings.

In the second specification, we use a continuous measure of the relative power of the second largest controlling shareholder versus the largest shareholder (Vote21). Consistent with the precedent result, the coefficient on this variable $\left(N I^{*} V O T E 21\right)$ is 0.1989 with a p-value less that 0.01, which suggests that earnings are more informative in firms where control is contestable. If the relative power increases by $1 \%$, the earnings response coefficient will be $1.2975 \%(0.1989 \% / 0.1533$ $=1.2975 \%$ ) higher every thing else being equal. Results remain qualitatively similar but significant at only $5 \%$ when we consider the relative power of the second and third largest shareholders to voting rights of the largest shareholder (Vote 231).

The results from the last specification in Table 6 confirm our previous conclusions. The coefficient on $\left(N I^{*}\right.$ Herfdvote $)$ is negative and statistically significant at the $1 \%$ level. This shows that the presence of controlling shareholders with comparable distribution of voting power curbs the extraction of private gains, hence reducing the accounting earnings management needed to veil potential opportunistic behavior and leading to better earnings information.

Overall, the results in specifications 1 through 4 show that the presence and voting size of large controlling blockholders beyond the dominant owner are associated with higher-quality earnings. These findings lend support to the argument that multiple large shareholders play a valuable governance role in mitigating the agency costs that arise between the controlling shareholder and minority shareholders. 


\section{Check of robustness}

This section is dedicated to check the robustness of our results by conducting several sensitivity tests. Only the results of some of them are reported for sake of brevity. First, we rerun all regressions by interacting MLS related variables with Excess control high which is a dummy variable that takes on a value of 1 for all observations where the value of Excess control is greater than the median of the sample, and zero otherwise. By doing so, we test whether multiple controlling shareholders are efficient in alleviating extreme agency problems that may arise from the conflict of interest between the largest controlling shareholder and minority shareholders and hence whether their presence strengthens the relation between accounting earnings and stock prices.

Consistent with previous findings, the coefficient on the interaction terms between Excess control high on one hand and MLSD, VOTE21 and Vote231 from the other hand are positive and statistically significant at least at $10 \%$ threshold level whereas the coefficient on the interaction term with HERFDVOTE is negative and statistically significant at the 10\% threshold level (See Table 7).

\section{Table 7}

Multiple large shareholders, excess control and earnings informativeness

\begin{tabular}{|c|c|c|c|c|c|c|c|c|}
\hline \multirow[b]{2}{*}{ Variables } & \multicolumn{2}{|c|}{$\begin{array}{l}\text { Specification } 1 \\
\text { Interaction with } \\
\text { MLSD }=1\end{array}$} & \multicolumn{2}{|c|}{$\begin{array}{c}\text { Specification } 2 \\
\text { Interaction with } \\
\text { VOTE21 }\end{array}$} & \multicolumn{2}{|c|}{$\begin{array}{c}\text { Specification } 3 \\
\text { Interaction with } \\
\text { VOTE231 }\end{array}$} & \multicolumn{2}{|c|}{$\begin{array}{c}\text { Specification } 4 \\
\text { Interaction with } \\
\text { HERFDVOTE }\end{array}$} \\
\hline & Coef. & $t$-value & Coef. & $t$-value & Coef. & $t$-value & Coef. & $t$-value \\
\hline NI & $0.1840^{\mathrm{a}}$ & $(2.8981)$ & $0.2025^{\mathrm{a}}$ & $(3.2963)$ & $0.2114^{\mathrm{a}}$ & $(3.4248)$ & $0.1783^{\mathrm{a}}$ & $(2.6055)$ \\
\hline $\mathrm{NI} * \mathrm{UCF}$ & $0.0603^{\mathrm{a}}$ & $(4.5142)$ & $0.0550^{\mathrm{a}}$ & (3.9583) & $0.0524^{\mathrm{a}}$ & $(3.4193)$ & $0.0602^{\mathrm{a}}$ & $(4.0889)$ \\
\hline NI*Excess control & $-0.0799^{\mathrm{a}}$ & $(-10.9288)$ & $-0.7802^{\mathrm{a}}$ & $(-9.5363)$ & $-0.0764^{\mathrm{a}}$ & $(-7.9615)$ & $-0.0705^{\mathrm{a}}$ & $(-7.2175)$ \\
\hline $\begin{array}{l}\text { NI*Excess control } \\
\text { high *MLSD =1 }\end{array}$ & $0.1840^{\mathrm{b}}$ & $(1.9655)$ & & & & & & \\
\hline $\begin{array}{l}\text { NI*Excess control } \\
\text { high *VOTE21 }\end{array}$ & & & $0.1383^{\mathrm{b}}$ & $(2.0123)$ & & & & \\
\hline $\begin{array}{l}\text { NI**Excess control } \\
\text { high*VOTE231 }\end{array}$ & & & & & $0.0623^{c}$ & $(1.9012)$ & & \\
\hline $\begin{array}{l}\text { NI*Excess control } \\
\text { high*HERFDVOTE }\end{array}$ & & & & & & & $-0.2212^{\mathrm{c}}$ & $(-1.7118)$ \\
\hline \multicolumn{9}{|l|}{ Control Variables } \\
\hline NI*Firm size & -0.0005 & $(-0.1814)$ & -0.0006 & $(-0.2238)$ & -0.0001 & $(-0.0352)$ & 0.0003 & $(0.1123)$ \\
\hline $\mathrm{NI} * \mathrm{Q}$ & $0.0007^{\mathrm{b}}$ & $(1.9931)$ & $0.0005^{\mathrm{c}}$ & $(1.8934)$ & $0.0005^{\mathrm{c}}$ & $(1.9125)$ & $0.0007^{\mathrm{b}}$ & (1.9978) \\
\hline NI*Leverage & $-0.0015^{\mathrm{b}}$ & $(-2.1532)$ & $-0.0011^{\mathrm{c}}$ & $(-1.9398)$ & $-0.0010^{\mathrm{c}}$ & $(-1.7025)$ & $-0.0015^{b}$ & $(-2.0670)$ \\
\hline $\begin{array}{l}\text { NI*Industry } \\
\text { diversification }\end{array}$ & $-0.0055^{\mathrm{b}}$ & $(-2.3125)$ & $-0.0076^{\mathrm{b}}$ & $(-2.2178)$ & $-0.0109^{\mathrm{b}}$ & $(-2.2756)$ & $-0.0080^{\mathrm{b}}$ & $(-2.1106)$ \\
\hline Industry dummies & \multicolumn{2}{|c|}{ YES } & \multicolumn{2}{|c|}{ YES } & \multicolumn{2}{|c|}{ YES } & \multicolumn{2}{|c|}{ YES } \\
\hline Constant & $-0.0556^{\mathrm{b}}$ & $(-1.9932)$ & $-0.0573^{\mathrm{b}}$ & $(-2.0612)$ & $-0.0581 b$ & $(-2.0878)$ & $-0.0564^{\mathrm{b}}$ & $(-2.0245)$ \\
\hline F-Value & \multicolumn{2}{|c|}{$15.31^{\mathrm{a}}$} & \multicolumn{2}{|c|}{$12.48^{\mathrm{a}}$} & \multicolumn{2}{|c|}{$9.55^{\mathrm{a}}$} & \multicolumn{2}{|c|}{$41.81^{\mathrm{a}}$} \\
\hline Adjusted R-squared & \multicolumn{2}{|c|}{$6.75 \%$} & \multicolumn{2}{|c|}{$6.60 \%$} & \multicolumn{2}{|c|}{$6.50 \%$} & \multicolumn{2}{|c|}{$6.64 \%$} \\
\hline $\begin{array}{l}\text { Number of } \\
\text { observations }\end{array}$ & \multicolumn{2}{|c|}{2384} & \multicolumn{2}{|c|}{2384} & \multicolumn{2}{|c|}{2384} & \multicolumn{2}{|c|}{2384} \\
\hline \multicolumn{9}{|c|}{$\begin{array}{l}\text { Table } 7 \text { tests the role of multiple controlling shareholders on earnings informativeness in firms exhibiting excess control. The } \\
\text { dependent variable is earnings informativeness proxied by the cumulative net-of-market } 12 \text {-month stock returns (CAR). Excess } \\
\text { control high is a dummy variable that takes on a value of } 1 \text { for all observations where the value of Excess control is greater than the } \\
\text { median of the sample, and zero otherwise. See Table } 1 \text { for the definition if the remaining variables. The t-statistics are based standard } \\
\text { errors with White (1980) correction for heteroscedasticity and adjusted for clustering for observations at the firm level. The symbols } \\
\text { a, b and c denote statistical significance at the } 1 \%, 5 \% \text { and } 10 \% \text { level, respectively. }\end{array}$} \\
\hline
\end{tabular}


These findings show that the negative effect of the separation between ultimate cash flow rights and control rights on earnings informativeness turns to be positive in the presence of multiple controlling shareholders or when control is contestable. Hence, the presence of multiple controlling shareholders does matter in the presence of a large divergence between the interests of the largest controlling shareholder and those of minority shareholders. Second, six percent of the sample firms are with atomistic ownership structure where the relevant conflict of interest is that between shareholders and professional managers. Empirically, we have assigned the value of zero to the Excess control of these widely held firms. Excluding them from the analysis do not seem to qualitatively change our results. Third, to be considered as a controlled entity, a firm must have a controlling owner who maintains at least $10 \%$ of the control rights. We re-estimate our regression using a tighter control threshold (20\% of the control rights). The results are qualitatively similar. Fourth, we rerun regressions using cumulative abnormal returns calculated differently to check the sensitivity of our results to alternative dependent variables. The conclusions remain virtually the same when (1) we use cumulative raw stock returns instead of the cumulative net-of-market stock returns or (2) we compute the CAR over the 39 (26) weeks prior to and 13 (26) weeks after the current fiscal year end. Finally, results do not vary to the use of the change in earnings $(\Delta N I)$ instead of earnings $(N I)$ or to the inclusion of additional controlling variables such as firm age, affiliation to a pyramid or loss firms which is a dummy variable that take one for firms with negative net income.

\section{Conclusion}

Prior research provides evidence that there is a relationship between ownership structure and the quality of firm earnings (see e.g., Fan and Wong, 2002). Using data on ultimate owners of French listed firms, this paper complements prior findings with respect to the effect of ultimate cash flow rights and excess control on the quality of firms' accounting information. It also extends this line of research to shed light on the effects of the presence of multiple controlling shareholders on firms' earnings informativeness.

The current study documents several interesting findings. First, we show that earnings informativeness is significantly positively related to the ultimate cash flow rights of the owner. This evidence is consistence with the alignment effect whereby stock ownership aligns management's interests with those of shareholders, which in turn reduces managers' incentives to manipulate accounting information. Second, we find that earnings informativeness is significantly negatively related to the excess control of the ultimate controlling shareholder. This result supports the entrenchment effect argument and suggests that controlling shareholders have greater incentives to 
undertake activities that hide their egregious behaviour when the potential expropriation of minority investors is substantial. Finally, and more importantly, we document the monitoring role of MLS and show that the presence and control size of multiple large shareholders translate into significantly greater earnings informativeness. Control contestability of the largest controlling shareholder mitigates information asymmetry problems thereby enhancing firms' earnings information.

\section{References}

Ali, A., Chen, T.-Y. and Radhakrishnan, S. (2007), "Corporate disclosures by family firms", Journal of Accounting and Economics, vol. 44, no. 1-2, pp. 238-286.

Admati, A.R., P. Pfleiderer, and Zechner, J. (1994), "Large Shareholder Activism, Risk Sharing, and Financial Market Equilibrium”, Journal of Political Economy, 02, 1097-1130.

Atiase, R. (1985), "Predisclosure Information, Firm Capitalization and Security Price Behavior around Earnings Announcements”, Journal of Accounting Research, 23 (Spring), 21-36.

Attig, N., W.-M, Fong, Y, Gadhoum, and L.H.P, Lang, (2006), "Effects of Large Shareholding on Information Asymmetry and Stock Liquidity", Journal of Banking and Finance 30, 2875-2892.

Attig, N., O. Guedhami, and D. Mishra, (2008), "Multiple Large Shareholders, Control Contests, and Implied Cost of Equity", Journal of Corporate Finance, 14, 721-737.

Attig, N., S, El Ghoul, and O. Guedhami, (2009), "Do Multiple Large Shareholders Play a Corporate Governance Role? Evidence from East Asia”, Journal of Financial Research, 32, 395422.

Ball, R., A, Robin, and Wu, J.S. (2003), "Incentives versus Standards: Properties of Accounting Income in Four East Asian Countries, and Implications for Acceptance of IAS", Journal of Accounting and Economics, 36, 235-270.

Bamber, L.S. (1987), "Unexpected Earnings, Firm Size and Trading Volume around Quarterly Earnings Announcements", The Accounting Review, 62, 510-532.

Bennedsen, M. and Wolfenzon, D. (2000), "The Balance of Power in Closely Held Corporations", Journal of Financial Economics, 58, 113-139.

Berle, A. and Means, G. (1932), The Modern Corporation and Private Property. Harcourt, Brace and World, New York.

Bertrand, M., P, Mehta, and S, Mullainathan, (2002), "Ferreting out Tunneling: An Application to Indian Business Groups”, Quarterly Journal of Economics, 117, 121-148.

Billings, B.K. (1999), "Revisiting the Relation between the Default Risk of Debt and the Earnings Response Coefficient", The Accounting Review, 74(4), 509-523.

Bloch, F. and Hege, U. (2001), "Multiple Shareholders and Control Contests", Aix-Marseille University working paper. 
Bolton, P. and Von Thadden, E.-L. (1998), "Blocks, Liquidity and Corporate Control”, Journal of Finance, 53, 1-25.

Boubaker, S. (2007), "Ownership-Control Discrepancy and Firm Value: Evidence from France", Multinational Finance Journal, Vol 11: 3\&4, p. 211-252.

Boubaker S. and Labegorre, F. (2008), “Ownership Structure, Corporate Governance and Analyst Following: A Study of French Listed Firms", Journal of Banking and Finance, 32, 961-976.

Boubakri, N., J.C. Cosset, and Guedhami, O. (2005), "Investor Protection, Corporate Governance and Privatization", Journal of Financial Economics, 76, 369-300.

Burkart, M., D. Gromb, and Panunzi, F. (1997), "Large Shareholders, Monitoring, and the Value of the Firm", Quarterly Journal of Economics, 112: 3, 693-728.

Campbell, J.Y. (1996), "Understanding risk and return", Journal of Political Economy, Vol. 104 pp.298-345.

Claessens, S., S. Djankov, J. Fan, and Lang, L. (2002), "Disentangling the Incentive and Entrenchment Effects of Large Shareholdings", The Journal of Finance, 57: 6, 2741-2771.

Claessens, S., S. Djankov, and Lang, L. (2000), "The Separation of Ownership and Control in East Asian Corporations”, Journal of Financial Economic, 58, 81-112.

Collins, D.W. and Kothari, S.P. (1989), "An Analysis of Intertemporal and Cross-sectional Determinants of Earnings Response Coefficients", Journal of Accounting and Economics (July), 143-181.

Demsetz, H. and Lehn, K. (1985), "The Structure of Corporate Ownership: Causes and Consequences”, Journal of Political Economy, 93, 1155-1177.

Denis D.J., Denis D.K, and Sarin, A. (1997), “Agency Problems, Equity Ownership and Corporate Diversification", The Journal of Finance, 52, 135-160.

Dhaliwal, D. S. and Reynolds, S. S. (1994), "The Effect of the Default Risk of Debt on the Earnings Response Coefficient", The Accounting Review, 69, 412-420.

Diamond W. D. and Verrecchia, R. E. (1991), "Disclosure, Liquidity, and the Cost of Capital", The Journal of Finance, 46: 4, 1325-1359

Faccio, M. and Lang L., (2002), "The Ultimate Ownership of Western European Corporations", Journal of Financial Economics, 65: 3, 365-395.

Faccio, M., L. H. P. Lang, and L. Young (2001), "Who Disciplines Management in Poorly Performing Companies?”, American Economic Review, 91: 1, 54-78.

Fama, E. F. and Jensen, M. C. (1983), "Separation of ownership and control", Journal of Law and Economics, 26, 301-325.

Fan, J. and Wong, T.J. (2002), "Corporate Ownership Structure and the Informativeness of Accounting Earnings in East Asia”, Journal of Accounting and Economics, 33, 401-425.

Faure-Grimaud, A. and Gromb D. (2004), "Public Trading and Private Incentives", Review of Financial Studies 17, 985-1014

Francis, J., K. Schipper and Vincent L. (2005), "Earnings and Dividend Informativeness when Cash Flow Rights are Separated from Voting Rights", Journal of accounting and economics, 39, 329360. 
Freeman, R.N. (1987), “The Association between Accounting Earnings and Security Returns for Large and Small Firms", Journal of Accounting and Economics, 9, 195-228.

Gelb, D.S. and P. Zarowin, (2002), "Corporate Disclosure Policy and the Informativeness of Stock Price", Review of Accounting Studies, 7(1), 33-53.

Gomes, A. (2000), "Going Public Without Governance: Managerial Reputation effects", The Journal of Finance 55 (2), 615-646.

Gomes, A. and Novaes, W. (2005), "Sharing of Control as a Corporate Governance Mechanism", Discussion Paper PIER Working paper 01-029, University of Pennsylvania Law School.

Grossman, S. and Hart, O. (1980), "Takeover Bids, the Free-rider Problem, and the Theory of the Corporation", The Bell Journal of Economics, 11, 42-64

Guedhami, O., and Mishra, D. (2009), "Excess Control, Corporate Governance, and Implied Cost of Equity: International Evidence”, Financial Review, 44, 489-524.

Gutierrez, M., and Tribo, J. A. (2004), "Private Benefits Extraction in Closely-Held Corporations: The Case for Multiple Large Shareholders", Discussion Paper 53/2004, ECGI.

Jensen, M. C., and Meckling, W. H. (1976), "Theory of the Firm: Managerial Behavior, Agency Costs, and Ownership Structure", Journal of Financial Economics, 3, 305-360.

Jung, K., and Kwon, S. Y. (2002), "Ownership Structure and Earnings Informativeness: Evidence from Korea", The International Journal of Accounting, 37, 301-325.

Kahn, C., and Winton, A. (1998), "Ownership Structure, Speculation, and Shareholder Intervention," The Journal of Finance, 53, 99- 130.

Kaplan, S.N., and Minton, B.A. (1994), "Appointments of Outsiders to Japanese Boards: Determinants and Implications for Managers", Journal of Financial Economics, 36, 225-258.

Laeven, L., and Levine, R. (2008), "Complex Ownership Structures and Corporate Valuations", Review of Financial Studies, 21, 579-604.

Lang, M.H., and Lundholm, R.J. (2000), "Voluntary Disclosure and Equity Offerings: Reducing Information Asymmetry or Hyping the Stock?", Contemporary Accounting Research, 17: 4, 623662.

La Porta, R., F. Lopez-de-Silanes, and Shleifer, A. (1999), "Corporate Ownership around the World", The Journal of Finance, 54, 471-517.

La Porta, R., Lopez-de-Silanes, F., Shleifer, A. and Vishny, R. (2000), "Investor protection and corporate governance", Journal of Financial Economics 58, 3-27.

La Porta, R., Lopez-de-Silanes, F., Shleifer, A. and Vishny, R. (2002), "Investor protection and corporate valuation", The Journal of Finance, 57, 1147-1170.

Leftwich, R., Watts, R, and Zimmerman, J. (1981), "Voluntary Corporate Disclosure: The Case of Interim Reporting", Journal of Accounting Research, 19 (Supplement), 50-77.

Lehmann, E., and Weigand, J. (2000), "Does the Governed Corporation Perform Better? Governance Structures and Corporate Performance in Germany", European Finance Review, 4: 2, 157-195. 
Maug, E. (1998), "Large Shareholders as Monitors: Is there a Trade-off between Liquidity and Control?", The Journal of Finance, 53: 1, 65-98.

Maury, B., and Pajuste, A. (2005), "Multiple Large Shareholders and Firm Value", Journal of Banking and Finance, 29: 7, 1813-1834.

Noe, T. H. (2002), "Investor Activism and Financial Market Structure", Review of Financial Studies, 15: 1, 289-318.

Pagano, M., and Röell, A. (1998), "The Choice of Stock Ownership Structure: Agency Costs, Monitoring, and the Decision to Go Public", Quarterly Journal of Economics, 113: 1, 187-226.

Shleifer, A., and Vishny, R. W. (1986), "Large Shareholders and Corporate Control", Journal of Political Economy, 94: 3, 461-488.

Shleifer, A., and Vishny, R.W. (1997), “A Survey of Corporate Governance”, Journal of Finance, 52, 737-783.

Smith, C.W., and Watts, R.L. (1992), "The Investment Opportunity Set and Corporate Financing, Dividend and Compensation Policies”, Journal of Financial Economics, 263-292.

Thomsen, S., T. Pedersen, and Kvist K. (2006), "Blockholder Ownership: Effects on Firm Value in Market and Control Based Governance Systems", Journal of Corporate Finance, 12, 246-249.

Villalonga, B. and Amit R. (2006), "How do family ownership, control and management affect firm value?", Journal of Financial Economics 80, 385-417.

Volpin, P. (2002), "Governance with Poor Investor Protection: Evidence from Top Executive Turnover in Italy”, Journal of Financial Economics, 64: 1, 61-90.

Warfield, T., J. Wild, and Wild K. (1995), "Managerial Ownership, Accounting Choices and Informativeness of Earnings", Journal of Accounting and Economics, 20, 61-91.

Winton, A. (1993), "Limitations of liability and the ownership structure of the firm", Journal of Finance, 48, 487-512.

White, H. (1980), “A heteroskedastic-consistent Covariance Matrix Estimator and a Direct Test of Heteroskedasticity”, Econometrica, 48, 817-838.

Yafeh, Y., and Yosha Y. (2003), “Large Shareholders and Banks: Who Monitors and How?", The Economic Journal, 113, 128-146.

Yeo, G., P. Tan, K. Ho, and Chen S. (2002), "Corporate Ownership Structure and the Informativeness of Earnings”, Journal of Business, Finance and Accounting, 29, 1023-1046.

Zwiebel, J. (1995), "Block Investment and Partial Benefits of Corporate Control”, The Review of Economic Studies, 161-185. 